\title{
Uloga kompetencije kreativnosti i socijalne kompetencije u nastavi vjeronauka
}

\author{
Marjan Ninčević*, Dunja Jurić**
}

\begin{abstract}
Sažetak
Kompetencija se u kontekstu uloge nastavnika određuje kao profesionalna mjerodavnost visoke stručne razine; kvalitetna pedagoška izobraženost i osposobljenost koje su stečene pedagoškom izobrazbom i stalnim pedagoškim usavršavanjem. Posebno značenje pri izgradnji podržavajućeg odnosa s učenicima i profiliranju uspješnog nastavnika imaju kompetencija kreativnosti i socijalna kompetencija, kao izvori motivacije, pretpostavke razvoja kreativnosti učenika i konstruktivne komunikacije između nastavnika i učenika. Posebno se to odnosi na nastavu vjeronauka, predmeta koji promiče cjelovit odgoj i obrazovanje učenika te ističe osobne, društvene, vjerničke i općeljudske vrednote. Stoga je cilj ovoga rada bio utvrditi razinu samoprocjene socijalne kompetencije i kompetencije kreativnosti srednjoškolskih vjeroučitelja u Republici Hrvatskoj. U istraživanju su 304 vjeroučitelja procijenila svoje kompetencije ispunjavanjem upitnika Pedagoško-kompetencijski profil vjeroučitelja. Utvrđena je značajna razlika u procjeni važnosti socijalne kompetencije između muškaraca $i$ žena, pri čemu žene navedenu kompetenciju procjenjuju važnijom u odnosu na muškarce. Nije pronađena razlika u procjeni važnosti kompetencije kreativnosti s obzirom na spol, kao ni razlika u procjenama kompetencije kreativnosti $i$ socijalne kompetencije s obzirom na vrstu škole, trajanje staža i status sudionika. Dobiveni su rezultati promatrani u svjetlu suvremenih istraživanja pedagoških kompetencija, čimbenika koji ih određuju i implikacija koje ostvaruju.

Ključne riječi: pedagoške kompetencije, vjeronauk, kompetencija kreativnosti, socijalna kompetencija
\end{abstract}

\section{Uvod}

Pojam kompetencije pojam je u izgradnji, definiran na brojne i različite načine ovisne o kontekstu, te s tim u vezi postoje i različita shvaćanja suvremene pe-

* Doc. dr. sc. Marjan Ninčević, Hrvatski studiji Sveučilišta u Zagrebu. Adresa: Borongajska c. 83d, 10000 Zagreb, Hrvatska. E-pošta: mnincevic@hrstud.hr

** Dunja Jurić, mag. psych., Hrvatski studiji Sveučilišta u Zagrebu. Adresa: Borongajska c. 83d, 10000 Zagreb, Hrvatska. E-pošta: djuric@hrstud.hr 
dagoške kompetencije. ${ }^{1}$ Kao jedna od temeljnih psiholoških potreba, ${ }^{2}$ kombinacija znanja, vještina, stajališta i osobnih karakteristika koje omogućuju pojedincu aktivno sudjelovanje u nekoj situaciji te analiziranje i interpretiranje te situacije, ${ }^{3}$ kompetencija se opisuje i kao sposobnost ulaženja u transakcije s promjenjivom i izazovnom okolinom, što za posljedicu ima razvoj i sazrijevanje pojedinca. ${ }^{4} \mathrm{U}$ kontekstu učiteljske uloge, pedagoške su kompetencije najprimjerenije definirane kao profesionalna mjerodavnost visoke stručne razine, u smislu kvalitetne pedagoške izobraženosti i osposobljenosti učiteljstva, koje su stečene pedagoškom izobrazbom i stalnim pedagoškim usavršavanjem. ${ }^{5}$ Pedagoška literatura ističe značajnost i odgovornost nastavnikove uloge, kao i potrebu za razvojem pedagoških kompetencija, a novija su istraživanja usmjerena na kompetencije učitelja, nastavnika, profesora i studenata učiteljskih fakulteta, kako bi dobili informaciju o odlikama koje bi suvremeni nastavnici trebali posjedovati. Pedagoške kompetencije obuhvaćaju niz vještina, od općenitih pitanja egzistencijalne naravi, kao što je vladanje složenošću i konfrontiranje sa sustavima značenja, do konkretnijeg operativnog djelovanja, primjerice organizacijskih sposobnosti, a mogu se podijeliti na tri skupine: opće pedagoško-psihološko obrazovanje učitelja; osobine vezane uz organiziranje odgojno-obrazovnog procesa te osobine važne za uspostavljanje međuljudskog odnosa između učenika i učitelja. ${ }^{6} \mathrm{U}$ dokumentu Improving competences for the 21st Century: An Agenda for European Cooperation on Schools, Komisija za europske zajednice iznosi preporuke za razvoj pedagoških kompetencija, ističući potrebu za razvijanjem složenijih vještina i prilagodljivosti, sposobnosti samoreguliranog i cjeloživotnog učenja, građanskog angažmana i aktivizma, te osam ključnih kompetencija za cjeloživotno učenje: kritičko mišljenje, kreativnost, inicijativu, rješavanje problema, procjenu rizika, odlučivanje te konstruktivno upravljanje osjećajima. ${ }^{7}$ Sve se navedeno može primijeniti i na nastavu školskoga vjeronauka, predmeta kojemu je cilj pružiti cjelovito poznavanje katoličke vjere, pomoć učenicima u razvoju vlastitih duhovnih sposobnosti, etičko-moralne svijesti i vrijednosti te kritičkog odnosa prema životu i svijetu. ${ }^{8}$ Od vjeroučitelja se ne očekuje samo prenošenje znanja, nego da ga znaju primijeniti

1 M. Jurčić, Pedagoške kompetencije suvremenog učitelja, Zagreb, 2012.

2 W. Glasser, Teorija izbora - nova psihologija osobne slobode, prev. Mirjana Zećirević, Zagreb, 2000.

3 N. Hrvatić - M. Bartulović, Škola budućnosti: nove kompetencije učitelja, Križevački pedagoški dani, 2007, 15.

4 S. Opić - A. Jurčević-Lozančić, Kompetencije učitelja za provedbu pedagoške prevencije poremećaja u ponašanju, Odgojne znanosti, 2008, 10, 15, 181-194.

5 A. Mijatović, Leksikon temeljnih pedagoških pojmova, Zagreb, 2000.

6 V. Strugar, Učitelj — temeljni nositelj sustava odgoja i obrazovanja - u: A. Mijatović (ur.), Osnove suvremene pedagogije, Zagreb, 1999, 399-421.

7 D. Lončarić - P. Pejić Papak, Profiliranje učiteljskih kompetencija, Odgojne znanosti, 11, 2, 479- 497.

8 Hrvatska biskupska konferencija, Program nastave katoličkoga vjeronauka za srednje škole, Katehetski salezijanski centar, Zagreb, 2002, 11. 
kao teologiju u životnoj praksi; ne uvoditi učenike izolirano u teološku enciklopediju, nego u vježbanje mišljenja, ponašanja, promišljanja i stava prema stvarnosti religije i kršćanskoj vjeri, pri čemu obje — i religija i vjera — stoje u odnosu prema vlastitomu i zajedničkomu životu uopće. U multikulturalnom okruženju uloga je vjeroučitelja osposobiti učenika za komunikaciju i prihvaćanje ljudi koji su različiti od njega, stavljajući pritom u središte međuljudski odnos između učitelja i učenika i formirajući dinamičnu, stvaralačku, socijalnu i humanu školsku zajednicu. ${ }^{9}$ Suvremena odgojno-obrazovna praksa treba prosvjetnog djelatnika koji će trajno unaprjeđivati sebe kao osobu i profesionalca, nadograđivati i usavršavati svoje kompetencije te kritički promišljati i mijenjati svoju sadašnjost kako bi bio uspješniji u budućnosti.

Posebno značenje u odgoju i obrazovanju ima kreativnost, kroz koju učitelj pronalazi motivaciju za svoju aktivnost i koja predstavlja jednu od temeljnih pretpostavki razvoja kreativnoga učenika. ${ }^{10}$ Složenost toga konstrukta donekle otežava njezino precizno određenje. Interes za istraživanja kreativnosti potaknuo je Joy Paul Guilford sredinom 20. stoljeća podijelivši ljudsko mišljenje na konvergentno i divergentno. Divergentno mišljenje Guilford ${ }^{11}$ opisuje kao osnovnu karakteristiku kreativnosti. Kompetencija kreativnosti podrazumijeva stvaranje ideja za koje je bitno, dakle, divergentno mišljenje, ali i produbljivanje ideja kojega je značajka konvergentno mišljenje; otvorenost za istraživanje novih ideja, uzimanje u obzir vlastite intuicije. ${ }^{12}$ Obuhvaćanjem različitih aspekata brojnih određenja kreativnosti, moguće ju je odrediti kao urođenu sposobnost pojedinca da proizvodi određenu novinu na već postojeće stanje, bilo u materijalnoj, bilo u duhovnoj sferi. To se može odnositi na rješenja, ideje, umjetničke oblike, teorije ili proizvode, a nužno je da je ta novina originalna, ekonomična i primjenjiva unutar određenoga socijalnog konteksta, te da je pozitivno usmjerena. ${ }^{13}$ Dodatne teškoće u proučavanju toga fenomena stvara činjenica da je od početnih istraživanja razvijeno nekoliko teorijskih pristupa. Lubart ${ }^{14}$ opisuje pet dominantnih pristupa: mistični, psihodinamski, kognitivni, socijalno-psihološki i konfluentni pristup. Prema mističnom je pristupu kreativnost neobjašnjiv pojam koji se pripisuje nadnaravnom, dok je kreativnost prema psihodinamskom pristupu posljedica napetosti između svjesne realnosti i nesvjesnih nagona. Ko-

9 Neven Hrvatić - Marija Bartulović, Škola budućnosti: nove kompetencije učitelja. Križevački pedagoški dani, Križevci, 2007, 15, 56-67.

10 I. Somolanji — L. Bognar, Kreativnost u osnovnoškolskim uvjetima, Život i škola: časopis za teoriju i praksu odgoja i obrazovanja, Zagreb, 2008, 54, 19, 87-94.

11 J. P. Guilford, Creativity: Its measurement and development, A source book for creative thinking, 1962, 151-167.

12 L. Bognar - B. Bognar, Kreativnost učitelja kao značajna kompetencija nastavničke profesije, Zbornik radova Kompetencije i kompetentnost učitelja, 2007.

13 I. Somolanji — L. Bognar, Kreativnost u osnovnoškolskim uvjetima, Život i škola: časopis za teoriju i praksu odgoja i obrazovanja, 2008, 54, 19, 87-94.

14 T. Lubart, Creativity. Thinking and Problem Solving, 1994, 289-332. 
gnitivni pristup opisuje kreativnost kao dio šireg procesa razmišljanja umjesto kao nezavisan proces, a socijalno-psihološki pristup ističe ulogu motivacije, društvenoga okruženja i osobina ličnosti kao najvažnije aspekte kreativnoga procesa. Konfluentni pristup obuhvaća kognitivni, psihološki i socijalni pristup, naglašavajući pritom važnost utjecaja okoline. Svi se opisani pristupi slažu da je kreativno mišljenje najviša mentalna funkcija i vrh ljudskog postignuća. Kreativan nastavnik trebao bi imati izraženu potrebu za inovacijama: biti gorljivo zainteresiran za područje o kojem predaje, željan novosti, znatiželjan za sve što se događa unutar njegova kruga utjecaja. U suvremenom kurikulumu kreativnost je uvjetovana raznolikošću jer znamo da ne postoji »standardan učenik «: učenici mogu preferirati vizualno, akustično ili kinestetičko primanje informacija, mogu biti ljevaci ili dešnjaci, psihološki homogeni ili s izraženom asimetrijom između senzornog i logičkog planiranja, pamćenja i rezoniranja ili između tipova razmišljanja — reproduktivnog ili kreativnog, analitičkog i sintetičkog, vertikalnog i lateralnog. ${ }^{15}$

Od spomenutih Guilfordovih istraživanja pa sve do danas, integracija kreativnosti i obrazovanja ostala je kontroverzan psihologijski i pedagoški cilj. ${ }^{16}$ Zanimanje za utjecaj kreativnosti na odgojne procese i danas je izraženo, a osobito na polju zanimanja koja su okrenuta službi osobe, povećanje kreativnog potencijala pitanje je neprestanog zauzimanja na obrazovnom putu osobe kako bi se osigurale sve više i značajnije razine kompetentnosti i profesionalnosti. ${ }^{17}$

Značajan čimbenik kvalitete rada nastavnika je i socijalna kompetencija, čije se sastavnice kreću od sposobnosti otvorenog komuniciranja, osiguravanja pozitivnog ozračja, optimizma i empatije, do fleksibilnosti i procjena stilova vođenja. ${ }^{18}$ Socijalna kompetencija doprinosi vještini odgovora na stresne situacije, a sadrži pet elemenata. Element samosvijesti odnosi se na vještinu točnog prepoznavanja emocija i misli, kao i njihova utjecaja na ponašanje, što podrazumijeva adekvatnu procjenu nečijih snaga i slabosti, povjerenje i optimizam. Nadalje, učinkovito upravljanje vlastitim emocijama, mislima i ponašanjem u različitim situacijama podrazumijeva upravljanje stresom, kontrolu nagona, samomotivaciju, postavljanje ciljeva i upornost u postizanju istih. Društvena se svijest odnosi na vještinu preuzimanja perspektive i empatiziranja s drugima iz različitih kultura, razumijevanje socijalnih i etičkih normi ponašanja, te prepoznavanje potpore od obitelji i društvene zajednice. Vještina uspostavljanja i održavanja zdravih odnosa s različitim pojedincima i skupinama uključuje jasnu komunikaciju, pažljivo

15 T. Suciu, The Importance of Creativity in Education. Bulletin of the Transilvania University of Brasov, Economic Sciences. Series V, 2014, 7, 2, 151.

16 M. H. Hanson, Converging Paths: Creativity Research and Educational Practice. Knowledge Quest, 2014, 42, 5, 8 .

17 M. Fullan, Educational Reforme as Continuous Improvement, u: Hawley, D., Rollie, D. (ur.), The Keys to Effective Sclools. London: Sage pub, 2002, 1-10.

18 J. Martinčević, Utjecaj socijalne kompetencije učitelja na provođenje cjelodnevnog boravka učenika u školi, Odgojne znanosti, 2010, 12, 2, 441-458. 
slušanje, suradnju, otpor neprimjerenomu društvenomu pritisku, konstruktivno rješavanje sukoba te traženje i pružanje pomoći kada je ona potrebna. Odgovorno donošenje odluka vještina je koja podrazumijeva konstruktivne izbore u pogledu vlastitog ponašanja i socijalnih interakcija, pri kojima se u obzir uzimaju etički standardi, sigurnost, društvene norme, realna procjena posljedica različitih radnji te vlastita dobrobit i dobrobit drugih. ${ }^{19}$ Socijalno i emocionalno kompetentni nastavnici razvijaju podržavajuć i ohrabrujuć odnos sa svojim učenicima, usmjeravajući se na njihove snage i sposobnosti, uspostavljajući i provodeći smjernice ponašanja na način koji potiče intrinzičnu motivaciju, vodeći studente kroz konfliktne situacije, ohrabrujući suradnju između učenika, ponašajući se kao model za primjerenu te poštujuću komunikaciju i prosocijalno ponašanje. Opisana su ponašanja nastavnika povezana s optimalnom socijalnom i emocionalnom razrednom klimom i željenim ishodima učenja. Optimalna razredna klima karakterizirana je malim brojem sukoba i niskim razinama ometajućeg ponašanja, jednostavnim prijelazima s jedne vrste aktivnosti na drugu, primjerenim izražavanjem emocija, uvažavajućom komunikacijom i efikasnim rješavanjem problema, izraženim interesima i usmjerenjem na zadatak te podrškom i razumijevanjem individualnih razlika i potreba učenika. ${ }^{20}$ Istraživanja u području neuroznanosti i teorija učenja pokazuju da su socijalna i emocionalna kompetencija ne samo pozitivno povezane s akademskim uspjehom, nego predstavljaju jedan od njegovih temeljnih preduvjeta. ${ }^{21}$ Stoga je važno izbjegavati najčešce zapreke uspješne i učinkovite komunikacije: naređivanje i zapovijedanje, prijetnje, držanje prodika, osuđivanje, kritiziranje i neodobravanje, interpretaciju, ismijavanje i sarkazam. Potrebno je raditi na unaprjeđenju vještine aktivnoga slušanja, koje implicira interakciju s učenikom i omogućuje povratnu informaciju i razumijevanje. Na taj način učenici uče upravljati snažnim emocijama i smiriti ih, razumiju da ih se ne trebaju bojati; lakše će doći do stvarnog izbora problema umjesto usmjeravanja na posljedice i sukob. Nadalje, aktivno slušanje olakšava učenicima rješavanje problema, odgovornost usmjerava na učenike i čini ih prijemčivijima za informacije te stvara pozitivan, blizak i povjerljiv odnos između nastavnika i učenika. Primjenjujući strategiju aktivnog slušanja, nastavnici izvještavaju i o učinkovitijem korištenju vremena za učenje i poučavanje. ${ }^{22}$ Komunikacijska didaktika osobito promatra socijalnu kompetenciju i označava je u polju napetosti između predmeta i odnosa. Sukobi su »testovi« iz socijalne kompetencije nastav-

19 E. Dorman, Building teachers' social-emotional competence through mindfulness practices, $\mathrm{Cu}$ rriculum and Teaching Dialogue, 2015, 17, 1-2, 103.

20 P. A. Jennings - M. T. Greenberg, The prosocial classroom: Teacher social and emotional competence in relation to student and classroom outcomes, Review of educational research, 2009, 79, $1,491-525$.

21 L. Weaver - M. Wilding, The five dimensions of engaged teaching: A practical guide for educators, Bloomington, 2013.

22 T. Suciu, The Importance of Creativity in Education, Bulletin of the Transilvania University of Brasov. Economic Sciences. Series V, 2014, 7, 2, 151. 
nika/vjeroučitelja, stoga se u sukobima može pokazati koje obilježje socijalna kompetencija može imati. Jedan od zadataka nastave jest obučavanje za rješavanje konfliktnih situacija — to ne znači tražiti sukobe, no tamo gdje se sukobi javljaju treba vježbati putove rješenja te omogućiti svim sudionicima da sačuvaju obraz. Konceptualizacijom mogućnosti djelovanja u konfliktu dolazimo do pet stilova rješavanja konflikata, koje razlikujemo prema tomu koliko puno ili malo djelatnici ulažu u sadržajno rješavanje problema. Kontinuum se odvija od pasivnog do aktivnog djelovanja. Pasivnima, u smislu na sadržaj usmjerena rješavanja sukoba, smatraju se stilovi izbjegavanja i pokrivanja, a aktivnima se mogu smatrati stilovi forsiranja i sučeljavanja. Druga razlika tiče se brige za dobru suradnju i integraciju interesa (razina odnosa). Kontinuum te osi seže od negativnog prema pozitivnom. Nizak stupanj brige o odnosima sadrže stilovi forsiranje i izbjegavanje (negativni), a veliku brigu o odnosima pokazuju stilovi pokrivanje i sučeljavanje. Stil traženja kompromisa nalazi se u sredini. U praksi postoje razlozi da se svaki od navedenih stilova primjenjuje u različitim situacijama. Vjeroučitelji imaju ulogu menadžera za sukobe: u razredu, u školi, na kolegiju i u kontaktu s roditeljima, pa se ta socijalna kompetencija ne smije omalovažavati. ${ }^{23}$

Odgoj vjere u pluralističkom svijetu zahtijeva kompetentne i profesionalne nastavnike vjeronauka, ${ }^{24}$ iz čega proizlaze određene specifičnosti vezane uz posebnu ulogu i zadatak vjeroučitelja, s obzirom na predmet koji poučava. U samopoimanju učitelja i učiteljica značajno mjesto zauzima samoprocjena ili metarazina njihove pedagoške kompetentnosti, ${ }^{25}$ pa se metoda samoprocjene činila primjerenom svrsi toga istraživanja: sustavnoj procjeni pedagoških kompetencija kreativnosti i socijalne kompetencije vjeroučitelja u srednjim školama u Republici Hrvatskoj, polazeći od stajališta da vjeroučitelj koji je u teološkom smislu kompetentan, a nije sposoban poučavati, posredovati, prenositi, didaktički organizirati nastavu, ne može biti ni uspješan nastavnik. ${ }^{26}$

23 G. Hilger - S. Leimgruber - H. G. Ziebertz, Vjeronaučna didaktika, prev. K. Tremljan, Zagreb, 2009.

24 G. Sovernigo, Educare alla fede: come elaborare un progetto, Bologna, 1996.

25 M. Ljubetić, Biti kompetentan roditelj, Zagreb, 2007.

26 R. Razum, Obrazovanje učitelja i nastavnika, Lađa, 2008, 3, 2, 18-33; V. Strugar, Religijska raznolikost i kvaliteta odgoja Obrazovanja, u: Rosić, V. (ur.), Kvaliteta u odgoju i obrazovanju. Zbornik radova, Rijeka, 1998; A. Hoblaj, Četrdeset godina dosadašnjeg i mogućnosti daljnjeg djelovanja Katehetskog instituta Katoličkoga bogoslovnog fakulteta Sveučilišta u Zagrebu, Katehetski glasnik, 2002, 4, 1, 101-107; A. T. Filipović, Aktualna pitanja religijske pedagogije i katehetike, Bogoslovska smotra, 2006, 76, 1, 147-172; G. Friedrich, Mjesto vjeroučitelja u suvremenoj školi. Lađa, 2008, 3, 2, 34-40; R. Razum, Obrazovanje učitelja i nastavnika, Lađa, 2008, 3, 2, $18-33$. 


\section{Metodologija istraživanja}

\subsection{Cilj istraživanja}

Cilj je ovoga istraživanja ispitati razinu samoprocjene pedagoške kompetencije kreativnosti i socijalne kompetencije nastavnika vjeronauka u srednjim školama u Republici Hrvatskoj.

\subsection{Sudionici}

U istraživanju, u kojem je kao metoda utvrđivanja pedagoške kompetentnosti srednjoškolskih vjeroučitelja korištena samoprocjena, sudjelovala su 304 vjeroučitelja od njih ukupno 420 u srednjim trogodišnjim i četverogodišnjim školama u Republici Hrvatskoj. Šezdeset i jedan posto sudionika bilo je ženskog spola, a trideset i devet posto sudionika muškog spola; pedeset i šest posto sudionika imalo je manje od deset godina staža, u odnosu na četrdeset i četiri posto sudionika s više od deset godina staža. Šezdeset i jedan posto sudionika predavalo je u četverogodišnjoj, a deset posto sudionika u trogodišnjoj srednjoj školi. Osamdeset i pet posto sudionika bili su laici, a petnaest posto svećenici ili časne sestre. Navedeni deskriptivni podatci prikazani su u Tablici 1 u poglavlju Rezultati.

\subsection{Instrument i postupak}

U ovom su istraživanju nezavisne varijable: spol, godine staža, status u Crkvi (laik, nelaik, tj. svećenik i časna sestra) te rad u trogodišnjoj ili četverogodišnjoj školi. Nezavisne varijable nalaze se u prvom dijelu upitnika — Pedagoško-kompetencijski profil vjeroučitelja (PKPV), konstruiranom za potrebe ovog istraživanja. Prvi se dio upitnika odnosi na opće podatke - nezavisne varijable, a u drugom dijelu nalazi se 175 tvrdnji (čestica) koje su podijeljene na 21 pitanje, na koje su sudionici na skalama Likertova tipa procjenjivali različite sposobnosti koje se smatraju prijeko potrebnima u nastavničkoj vjeroučiteljskoj profesiji.

Upitnik ima dovoljan raspon pitanja (tvrdnji, čestica) i pokriva bitne dijelove iz teorijskog dijela radnje. U radu su korišteni empirijski rezultati dobiveni metodom samoprocjene. Podatci su prikazani i obrađeni odgovarajućim postupcima deskriptivne i inferencijalne statistike. Hipoteze su provjerene univarijatnim korelacijama i testiranjem značajnosti razlika među skupinama (hi-kvadrat testom ili t-testom, ovisno o vrstama varijabli).

\section{Rezultati}

Tablica 1. Deskriptivni podatci

\begin{tabular}{cccclclll}
\hline \multicolumn{2}{c}{ Spol } & \multicolumn{2}{c}{ Staž } & \multicolumn{2}{c}{ Škola } & \multicolumn{2}{c}{ Status } \\
\cline { 1 - 4 } \cline { 6 - 8 } & 118 & $1-10$ & 170 & & Trogodišnja & 29 & Laik & 257 \\
$\check{Z}$ & 186 & $>10$ & 134 & & Četverogodišnja & 185 & Nelaik & 47 \\
\hline
\end{tabular}


Tablica 2. Deskriptivni parametri i značajnosti razlika u procjenama važnosti pojedinih znanja i vještina za uspješnost u radu s obzirom na spol, staž, školu i status

\begin{tabular}{llllll}
\hline Faktori & Spol & $\mathrm{N}$ & $\mathrm{M}$ & $\mathrm{Sd}$ & $\mathrm{t}(\mathrm{df})$ \\
\hline Kompetencija & $\mathrm{M}$ & 118 & 3,046 & 0,489 & $-0,709(302) ;$ \\
kreativnosti & $\check{\mathrm{Z}}$ & 186 & 3,088 & 0,513 & $\mathrm{p}>0,05$ \\
\hline Socijalna & $\mathrm{M}$ & 118 & 3,266 & 0,526 & $-3,577(302)^{* *} ;$ \\
kompetencija & $\check{Z}$ & 186 & 3,455 & 0,390 & $\mathrm{p}<0,01$ \\
\cline { 2 - 6 } & Staž & $\mathrm{N}$ & $\mathrm{M}$ & $\mathrm{Sd}$ & $\mathrm{t}(\mathrm{df})$ \\
\hline Kompetencija & $1-10$ & 170 & 3,064 & 0,506 & $-0,298(302) ;$ \\
kreativnosti & $>10$ & 134 & 3,082 & 0,502 & $\mathrm{p}>0,05$ \\
Socijalna & $1-10$ & 170 & 3,345 & 0,434 & $-1,587(302) ;$ \\
kompetencija & $>10$ & 134 & 3,429 & 0,481 & $\mathrm{p}>0,05$ \\
\cline { 2 - 6 } & Śkola & $\mathrm{N}$ & $\mathrm{M}$ & $\mathrm{Sd}$ & $\mathrm{t}(\mathrm{df})$ \\
\hline Kompetencija & Trogodišnja & 29 & 2,931 & 0,495 & $-1,642(212) ;$ \\
kreativnosti & Četverogodišnja & 185 & 3,100 & 0,518 & $\mathrm{p}>0,05$ \\
Socijalna & Trogodišnja & 29 & 3,301 & 0,329 & $-1,043(212) ;$ \\
kompetencija & Četverogodišnja & 185 & 3,397 & 0,475 & $\mathrm{p}>0,05$ \\
\hline \multirow{3}{*}{$\begin{array}{l}\text { Kompetencija } \\
\text { kreativnosti }\end{array}$} & Status & $\mathrm{N}$ & $\mathrm{M}$ & $\mathrm{Sd}$ & $\mathrm{t}(\mathrm{df})$ \\
\cline { 2 - 6 } Socijalna & Lelaik & 47 & 3,148 & 0,530 & $1,134(302) ;$ \\
kompetencija & Lelaik & 257 & 3,058 & 0,498 & $\mathrm{p}>0,05$ \\
\hline & Laik & 47 & 3,473 & 0,486 & $1,488(302) ;$ \\
\hline
\end{tabular}

**Razlika je značajna na razini $\mathrm{p}<0,01$.

Pri procjeni važnosti određenih znanja i vještina za nastavnikovu uspješnost u radu utvrđena je statistički značajna razlika u procjeni važnosti socijalne kompetencije $(\mathrm{t}=-3,577, \mathrm{p}=0,000)$ između muškaraca i žena, pri čemu žene navedene kompetencije procjenjuju važnijima u odnosu na muškarce (Tablica 2). Nije nađena statistički značajna razlika u procjenama važnosti pojedinih znanja i vještina za uspješnost u radu s obzirom na staž sudionika, odnosno nema statistički značajne razlike u procjeni važnosti kompetencije kreativnosti i socijalne kompetencije između sudionika čiji je radni staž od 1 do 10 godina i veći od 10 godina (Tablica 2). Razlike u procjenama važnosti kompetencije kreativnosti i socijalne kompetencije nisu pronađene s obzirom na vrstu škole u kojoj su sudionici zaposleni (trogodišnja ili četverogodišnja) te s obzirom na status sudionika (laik/nelaik). 


\section{Interpretacija rezultata i rasprava}

U svim područjima svojeg djelovanja pojedinac je trajno podvrgnut preispitivanju, ali i razvijanju svoje kompetentnosti, kako bi osigurao uspješnu prilagodbu okruženju, udovoljio zahtjevima društva, ali i samoga sebe. ${ }^{27}$ Pedagoška literatura ističe važnost i odgovornost nastavnikove uloge te naglašava potrebu za njegovom pedagoškom kompetencijom, što se odnosi i na nastavnike vjeronauka. Nastavnik treba stalno razvijati svoje kompetencije kako bi mogao koristiti se novim znanjima, osuvremenjivati ih, biti sposoban prilagođavati se određenomu kontekstu, kontinuirano se usavršavati i razumjeti ono što se uči, tako da se može prilagoditi novim okolnostima.

Katolički je vjeronauk jedan od predmeta u srednjoj školi i on po svojoj naravi i zadaći teži cjelovitu odgoju i promaknuću ljudske osobe kao pojedinca i člana društvene zajednice, te pridonosi ostvarivanju odgojno-obrazovnih ciljeva iz društveno-humanističkog područja. Vjeronauk učenicima pomaže da prepoznaju doprinos vjere/religije općeprihvaćenim ljudskim vrednotama, da uočavaju i znaju obrazložiti njezine specifičnosti i da kroz dijalog s vjerskim sadržajima, vrednotama i stavovima i sami postanu humanije osobe, te promiče njihovo religiozno i socijalno sazrijevanje. ${ }^{28}$

Vjeroučitelji su metodom samoprocjene procjenjivali pedagoške sposobnosti koje se smatraju potrebnima u nastavničkoj (vjeroučiteljskoj) profesiji: kompetenciju kreativnosti i socijalnu kompetenciju. Primijenjeno je anketno ispitivanje pomoću upitnika koji je konstruiran za potrebe istraživanja: Pedagoško-kompetencijski profil vjeroučitelja.

Između brojnih čimbenika koji određuju kompetencije, produktivnost i utjecaj nastavnika na školski uspjeh učenika često se ističe spol nastavnika. ${ }^{29}$ Općenito je, prema različitim istraživanjima, u sustavu osnovnog i srednjeg obrazovanja više žena u odnosu na muškarce. ${ }^{30}$ Neka istraživanja pokazuju da nastavnice izražavaju višu razinu zadovoljstva svojim zanimanjem i poslom u odnosu na nastavnike, a zadovoljstvo poslom pozitivno je povezano s visokom učinkovitošću i uspjehom u poslu. ${ }^{31}$ Tako je i u ovom istraživanju pri procjeni važnosti određenih znanja i vještina za nastavnikovu uspješnost u radu utvrđena statistički značajna

27 J. Coldron - R. Smith, Active location in teacher's construction of their professional identites, Journal of Curriculum Studies, 1999, 31, 6, 711-726.

28 J. Baričević, Konfesionalni vjeronauk u službi kulture dijaloga i mira, Katehetski glasnik, 2002, 4, 2, 147-149; J. Baloban, Vjeroučitelj — promicatelj duhovno odgojno-obrazovne sastavnice, Lada, 2008, 3, 2, 2-8.

29 R. M. Klassen - M. M. Chiu, Effects on teachers' self-efficacy and job satisfaction: Teacher gender, years of experience, and job stress, Journal of educational Psychology, 2010, 102, 3, 741.

30 A. Ammermüller - P. Dolton, Pupil-teacher gender interaction effects on scholastic outcomes in England and the USA, ZEW-Centre for European Economic Research Discussion Paper, 2006, 06- 060.

31 A. Somech - A. Drach-Zahavy, Understanding extra-role behavior in schools: The relationships between job satisfaction, sense of efficacy, and teachers' extra-role behavior, Teaching and Teacher Education, 16, 5, 649-659. 
razlika u procjeni važnosti socijalne kompetencije između muškaraca i žena. Žene navedenu kompetenciju procjenjuju važnijom u odnosu na muškarce. Ta bi se razlika u socijalnoj kompetenciji u korist žena mogla pripisati i eventualnoj izoštrenijoj percepciji žena kada je u pitanju pozitivan odnos između uspješnosti poučavanja i uspješnosti nastave. To, drugim riječima, znači da su žene sklonije ulozi refleksivnog učitelja i koriste se različitim povratnim informacijama, bolje ih razumijevaju i primjenjuju u svojem metodičkom napredovanju. Dodatno su zbog rodnih razlika žene socijalno osjetljivije s obzirom na podijeljenost socijalnih uloga utemeljenih na društvenom stereotipu.

Pri procjeni važnosti kompetencije kreativnosti nije pronađena statistički značajna razlika između muškaraca i žena. Razlike u procjenama važnosti pojedinih znanja i vještina za uspješnost u radu nisu pronađene niti s obzirom na status sudionika (laik/ nelaik) niti s obzirom na staž sudionika (1-10 godina i više od 10 godina).

\section{Zaključna razmatranja i prijedlozi}

Istraživanjem pedagoške kompetencije kreativnosti i socijalne kompetencije vjeroučitelja u srednjim školama Republike Hrvatske, metodom samoprocjene, ustanovljena je značajna razlika u procjeni važnosti socijalne kompetencije između muškaraca i žena, pri čemu žene navedenu kompetenciju procjenjuju važnijom u odnosu na muškarce. Nije pronađena razlika u procjeni važnosti kompetencije kreativnosti s obzirom na spol, kao ni razlika u procjenama kompetencije kreativnosti i socijalne kompetencije s obzirom na vrstu škole, trajanje staža i status sudionika. Istraživanjem literature utvrđeno je da u Republici Hrvatskoj od 1991. godine, kada je u školski sustav uveden vjeronauk, do danas nisu provođena sustavna ispitivanja pedagoške osposobljenosti vjeroučitelja za rad u školi. Doprinos ovoga istraživanja očituje se u rezultatima koji upućuju na važnost stjecanja pedagoških kompetencija tijekom inicijalnog i stručnog obrazovanja te usavršavanja nastavnika vjeronauka. Ovo istraživanje otvara prostor za buduća istraživanja u kojima bi bilo svrsishodno usporediti vjeroučiteljsku procjenu kompetentnosti s kompetentnošću ostalih nastavnika; istražiti mišljenje učenika o kompetencijama vjeroučitelja, provjeriti postoji li povezanost školskog uspjeha učenika i procjene pedagoških kompetencija vjeroučitelja, zatim ispitati mišljenje roditelja o zadovoljstvu djeteta kompetencijama vjeroučitelja te provjeriti utječe li predloženi model iz ovoga rada pozitivno na formalni uspjeh vjeroučitelja u školi. Također bi se mogla ispitati pedagoška kompetentnost vjeroučitelja u osnovnim školama i rezultate tog istraživanja usporediti s rezultatima iz ovog rada te uočiti eventualnu povezanost između kompetentnosti osnovnoškolskih vjeroučitelja s kompetentnošću srednjoškolskih vjeroučitelja. 
The Role of Creative Competencies and Social Competence in Teaching Catechism Marjan Ninčević*, Dunja Jurić**

\section{Summary}

In the context of teaching, competence is defined as a high level of professional expertise gained through quality schooling in the field of pedagogy and training attained at Teachers' College and through continuing specialization courses. Creative competencies and social competence are of special significance in building supportive relationships with students and in the shaping of an effective teacher. They are wellsprings of motivation and a prerequisite for developing creativity in students and for constructive teacher-student communication. This relates especially to Catechism class, a subject which promotes the students' integral development and education and also emphasizes personal, social, religious and universal human values. Therefore, the aim of this paper is to establish the level of self-assessment in the categories of social competence and creative competencies shown by secondary school Catechism teachers in the Republic of Croatia. Reasearch has demonstrated that 304 Catechism teachers assessed their aptitude by filling in a questionnaire titled Pedagogical-Competencies Profile of the Catechist. A significant difference between men and women was observed in their assessment of the importance of social competence, whereby women considered the latter to be of greater import than did men. No difference between the genders was found in their evaluation of the importance of creative competencies. The same was noted in regard to creative competencies and social competence concerning the type of school, duration of internship and participants' status. The results obtained were examined in light of contemporary research on teacher competencies, the factors which determine them and their implications.

Key words: teacher competencies, Catechism, creative competencies, social competence

* Senior Assistant Marjan Ninčević, Ph.D., Croatian Studies Department, University of Zagreb. Address: Borongajska c. 83d, 10000 Zagreb, Croatia. E-mail: mnincevic@hrstud.hr

** Dunja Jurić, mag. psych., Croatian Studies Department, University of Zagreb. Address: Borongajska c. 83d, 10000 Zagreb, Croatia. E-mail: djuric@hrstud.hr 